\title{
ИДЕНТИФИКАЦИЯ ПРОДУКТОВ ПРЕВРАЩЕНИЯ ФОСФОРОРГАНИЧЕСКИХ ОТРАВЛЯЮЩИХ ВЕЩЕСТВ МЕТОДОМ ВЭЖХ-МС/МС
}

Ленинский М.А., Савельева Е.И., Васильева И.А., Каракашев Г.В, Шачнева М.Д. ФГУП «НИИ ГПЭЧ» ФМБА России, г.п. Кузьмоловский, Россия

\section{m.leninskii@yandex.ru}

DOI: 10.26902/ASFE-11_120

Разработана процедура идентификации продуктов превращения фосфорорганических отравляющих веществ (ФОВ), образующихся в процессе детоксикации элементов инфраструктуры объектов по уничтожению химического оружия. В качестве аналитов выбраны персистентные вещества с высокой сорбционной активностью, а именно: российское вещество ви-икс (VR) и продукты его трансформации, а также продукты трансформации зарина и зомана. Уникальность предложенной процедуры заключается в возможности идентификации в рамках одного анализа двенадцати токсикантов, среди которых не только продукты гидролиза рассматриваемых ФОВ, но и продукты их детоксикации по Российской технологии с применением рецептур, содержавших в качестве активного ингредиента изобутилат калия. При гидролизе ФОВ образуются полярные алкилметилфосфоновые кислоты. При применении дегазирующих рецептур с изобутилатом калия (алкоголиз) происходило образование неполярных диэфиров метилфосфоновой кислоты вышеперечисленных ФОВ.

В исследуемый образец (смыв с поверхности или навеска измельченного твердого образца) вносили внутренний стандарт - параоксон, затем проводили экстракцию метанолом с последующим концентрированием экстракта в токе азота и добавлением к концентрированному экстракту аликвоты $0,1 \%$ водного раствора муравьиной кислоты. Полученную пробу анализировали методом ВЭЖХ-МС/MC в режиме мониторинга заданных реакций (MRM).

В случае обнаружения маркеров конверсии VR предусмотрено его количественное определение по разработанной нами и аттестованной методике измерений VR и токсичного продукта его гидролиза S-[(2-диэтиламино)этил] метилфосфонотиоата в смывах и твердых образцах (№ ФР.1.31.2020.36539).

Предложенные подходы применяются в рамках санитарно-химического обследования бывших объектов по уничтожению химического оружия на этапе их подготовки к перепрофилированию.

\section{Список источников}

1. Васильев И.А., Швыряев Б.В., Либерман Б.М., Шелученко В.В., Петрунин В.А., Горский В.Г. // Рос.хим.журнал. 1995. Т.39. Вып.4. С. $10-15$.

2. Демидюк В.В., Шалганова И.В., Широков А.Ю. Эколого-гигиеническая характеристика российской двухстадийной технологии химической детоксикации зарина, зомана, Ви-газов (предварительное сообщение). М.-СПб, 1998. 30 с.

3. Савельева Е., Ленинский М., Васильева И., Каракашев Г., Самченко Н. Определение следовых количеств Оизобутил-S-[(2-диэтиламино)этил] метилфосфонотиоата и токсичного продукта его гидролиза методом высокоэффективной жидкостной хроматографии с тандемным масс-спектрометрическим детектированием // Аналитика и контроль. 2021. Т.25. №3. С.43 